\title{
Ernst Freund as precursor of the rational study of corporate law
}

\author{
DAVID GINDIS* \\ Hertfordshire Business School, University of Hertfordshire, Hatfield AL10 9AB, UK
}

\begin{abstract}
The rise of large business corporations in the late 19th century compelled many American observers to admit that the nature of the corporation had yet to be understood. Published in this context, Ernst Freund's little-known The Legal Nature of Corporations (1897) was an original attempt to come to terms with a new legal and economic reality. But it can also be described, to paraphrase Oliver Wendell Holmes, as the earliest example of the rational study of corporate law. The paper shows that Freund had the intuitions of an institutional economist, and engaged in what today would be called comparative institutional analysis. Remarkably, his argument that the corporate form secures property against insider defection and against outsiders anticipated recent work on entity shielding and capital lock-in, and can be read as an early contribution to what today would be called the theory of the firm.
\end{abstract}

\section{Introduction}

Until recently few theorists of the firm subscribed to the idea that legal personality or legal entity status is an important part of the explanation of the nature of the firm. ${ }^{1}$ Likewise, legal entity status played little or no role in the economic analysis of corporate law. On the rare occasions when it was mentioned in either of these literatures the suggestion that firms and similar organizations are endowed by law with personhood, namely the capacity to attract rights and duties arising in legal relations, separate from the capacities of all the human beings involved, was dismissed as a convenient legal fiction or portrayed as a source of misleading reification (Easterbrook and Fischel, 1991; Jensen and Meckling, 1976; Klein, 1982; Meckling and Jensen, 1983; Posner, 1990; Tullock, 1971).

By contrast, legal entity status features prominently in more recent scholarship on the firm (Ayotte and Hansmann, 2015; Blair, 2012; Blair and Stout, 1999; Deakin et al., 2017; Deakin, forthcoming; Gindis, 2016; Hansmann and Kraakman, 2000a; Hodgson, 2002; Hansmann et al., 2006; Iacobucci and

\footnotetext{
*Email: d.gindis@herts.ac.uk.

I am indebted to Brian Cheffins, Nicola Giocoli, Henry Hansmann, Ron Harris, Samuel Mansell, Martin Petrin, Andrea Perrone, René Reich-Graefe, Malcolm Rutherford, Massimiliano Vatiero and two anonymous referees for useful comments on a previous version of this paper.

1 The terms 'legal personality' and 'legal entity status' are used interchangeably in this paper.
} 
Triantis, 2007; Kornhauser and MacLeod, 2013; Orts, 2013; Spulber, 2009; Triantis, 2012; Van den Steen, 2010). Much of this work revolves around two key claims: first, legal entity status fulfils important economic functions overlooked in previous research; and second, legal entity status requires what Henry Hansmann and Reinier Kraakman (2000a) call 'organizational law'. The functions performed by legal entity status cannot be created by contract alone.

When law assigns legal entity status to a firm set up by an entrepreneur or a group of entrepreneurs following some specified procedure (registration or incorporation) it creates a distinct legal person with a unified capacity for property, contract and litigation that is the focal point of the firm's economic activities. This legal person, in which ownership rights to assets are vested, performs the function of a transaction-cost economizing nexus for contracts with investors, suppliers, employees, customers and other parties, not simply because of the efficiency-enhancing property of contractual centralization noted long ago by Ronald Coase (1937), but also because 'asset partitioning' (Hansmann and Kraakman, 2000a, 2000b) allows the firm to bond its contractual and financial commitments irrespective of changes in its membership.

Following Hansmann, Kraakman and Richard Squire (2006), different types of firm can be distinguished depending on the degree of separation between the firm's assets and the founders' personal assets, and more precisely the degree to which the former are legally protected from the founders' personal creditors. All firms enjoy 'weak entity shielding', whereby the firm's creditors have priority over claims to the firm's assets made by the founders' personal creditors. But only a subset of firms benefit from 'strong entity shielding', the crucial tests being whether founders can unilaterally withdraw some or all of their share of the firm's assets, and whether the founders' personal creditors can force a partial liquidation of the firm's assets to satisfy their claims. ${ }^{3}$ These tests demarcate partnerships from corporations: only the latter benefit from the liquidation protection characteristic of strong entity shielding.

The corporation's advantage stems less from limited shareholder liability than from the fact that that corporate assets are literally 'locked-in', to borrow Margaret Blair's (2004) expression, without locking in any particular investors. ${ }^{4}$

2 Organizational law comprises 'the bodies of law that govern standard legal entities such as business corporations, partnerships, cooperatives, non-profit organizations, trusts [and] limited liability companies' (Hansmann and Kraakman, 2000b: 807).

3 To achieve even weak entity shielding by contract an entrepreneur would need to get personal creditors to agree to subordinate their claims to those of business creditors, and to credibly promise business creditors that all past and future personal creditors have and will agree to subordinate their claims. To sustain these commitments by contract would be a "transaction-cost nightmare"' (Langlois, forthcoming).

4 Limited liability, or 'owner shielding' in Hansmann, Kraakman and Squire's (2006) terminology, is a supporting feature that can potentially be achieved by contract. 
This allows investors to diversify and capital markets to develop, favoring the operation of large firms by facilitating the accumulation of equity in view of building up long-term investments. Specific investments that may otherwise be foregone, given the collective action and commitment problems inherent in team production situations, are further enhanced by the fact that corporate assets are controlled by an independent board whose primary concern, according to Blair and Lynn Stout (1999), is to balance the competing interests of all those involved in order to protect the firm's going concern value over time.

This paper argues that the main thrust of this more recent scholarship was anticipated by Ernst Freund in a little-known book, The Legal Nature of Corporations, published in 1897.5 Some historians of American corporate law have identified Freund as an 'important theorist' (Millon, 1990: 215) and have characterized his book as a 'brilliant exposition' (Mark, 1987: 1474) of the 'theoretical underpinnings of corporation law' (Carrington, 1994: 488, n.11). Yet to date references to this 'brilliant study' (Horwitz, 1985: 202), which was arguably well 'ahead of its time' (Harris, 2006: 1472), are rare, and a systematic assessment of its contributions remains unavailable. The purpose of this paper is to propose such an assessment, and to show why Freund's recognition as an important corporate theorist is long overdue.

Published at a time when the rise of business corporations compelled many American observers, including leading economists and lawyers, to admit that the nature of the corporation had yet to be understood, Freund's book represented an original attempt to come to terms with a new legal and economic reality. But more importantly, it can best be described, to paraphrase Oliver Wendell Holmes, as the earliest example of the 'rational study' of corporate law. Indeed, Freund devoted himself to the 'study of the ends sought' by corporate law 'and the reasons for desiring them' (Holmes, 1897: 1005). ${ }^{6}$ The paper shows that Freund

5 Freund (1864-1932) was born in New York but grew up and was educated in Germany. After obtaining a doctorate in law from Heidelberg in 1884 he practised law in New York. In 1894, while pursuing doctoral studies in political science at Columbia, the result of which was published as The Legal Nature of Corporations, he joined the faculty of political science at the recently-founded University of Chicago. When the Law School opened in 1902 Freund was a member of its original faculty, playing a significant role in the design of its distinctive interdisciplinary curriculum (Ellsworth, 1977; Mordfin and Nagorsky, 2011). Best known as a pioneer of American administrative law, he was also a founder of the American Political Science Association and a member of the National Conference of Commissioners on Uniform State Laws (Allen, 1965; Ernst, 2014; Firmage, 1962; Kent, 1933; Kraines, 1974). His major works are Police Power (Freund, 1904), Standards of American Legislation (Freund, 1917) and Administrative Powers of Persons and Property (Freund, 1928).

6 Holmes (1897) famously called for the 'rational study of law' that examined the reasons for legal rules in terms of their social value instead of merely referring, as was then customary, to court cases and authorities from the past. Exponents of the rational approach, Holmes predicted, would mobilize statistics and economics in assessing the ends, means and costs of rules. Freund was not a man of statistics but shared this conception of legal science. 
had the intuitions of an institutional economist, and engaged, implicitly at least, in what today would be called comparative institutional analysis. Moreover, it is possible to read his argument about the value of legal entity status as an early contribution to what today would be recognized as the theory of the firm.

Although Freund's analysis was rudimentary by today's standards, his claims that the corporate form secures property both against insider defection and against outsiders in ways unavailable in partnerships, and that law is necessary to achieve this result, sound remarkably prescient. In order to establish why 'Freund deserves to be rediscovered' (Reitz, 1993: 435) as an unjustly neglected precursor of contemporary work on firms and legal entities, this paper is organized as follows. Section 2 provides context by underlining the state of the late 19thcentury American understanding of corporations. A detailed examination of Freund's corporate theory follows in section 3, while section 4 reflects on its relevance both then and now, with a specific focus on the similarities between Freund's ideas and recent work on the firm. Section 5 concludes.

\section{Corporate theory in 19th-century America}

The generally accepted narrative regarding the development of 19th-century theories of the corporation in America draws parallels with the transformations of corporate law itself (Horwitz, 1992; Hurst, 1970). Prior to the widespread liberalization of state incorporation laws in the late 19th century, when special charters were granted primarily to ventures, such as utilities and banks, that were deemed to be in the public interest (Evans, 1948), incorporation was viewed as a state-granted privilege or franchise. According to this 'concession theory' of the corporation, accepted by luminaries such as James Kent (1827) or Joseph K. Angell and Samuel Ames (1832), and duly upheld by the Supreme Court, corporations were state-created artificial persons whose powers were strictly limited by their charters, with the implication that acts not explicitly authorized by the state and expressed as such in their charters were legally null and void. ${ }^{7}$

But as special charters came to be associated with legislative favoritism, a key feature of post-Jacksonian populist reform was to make charters 'freely' available, and incorporation under general statutes a simple administrative matter (Hovenkamp, 1991; Hurst, 1982). By the 1880s any group of corporators, regardless of the object of their venture, obtained the right to incorporate by simple registration, at a standard fee, provided that a certain set of requirements was met. In the laissez-faire setting of the Gilded Age, the period that witnessed

7 The notion that the state grants 'artificial personality' to corporations, as distinct from the 'natural personality' of man, goes back to Roman law. In the Middle Ages this distinction acquired a theological justification: since only divine power could create true persons endowed with reason and a soul, the persons created by secular powers must be artificial, fictitious and soulless. 
the emergence of American industrial capitalism, the principle that corporations were public concessions of privileges gave way to the view that corporations were the products of private rights and freedom of contract, in appearance confirming Henry Sumner Maine's (1861) observation that progressive societies were driven by a movement 'from status to contract'.

In this context, the new corporate theory proposed in A Treatise on the Law of Private Corporations by Wall Street corporate lawyer Victor Morawetz (1882) suggested that 'the idea of a corporation d[id] not necessarily imply a grant of corporate power by statute' (Morawetz, 1882: 24). The doctrine that corporations existed and acted 'only when authorized by ... the legislature', Morawetz (1882: 3) pointed out, failed to come to terms with the facts. Unincorporated associations were often 'considered as personified entities, acting as a unit, and in one name' (Morawetz, 1882: 24) both in business dealings and in the courts, and although 'unauthorized use[s] of corporate powers' and acts performed by de facto corporations, namely 'corporation[s] existing without authority of law' (Morawetz, 1882: 134), were punishable by the state, courts often viewed them as legally valid in order to avoid injustice to third parties.

The differences between corporations and partnerships, Morawetz reasoned, were less important than was commonly assumed. Both were voluntary associations 'formed by agreement of [their] members for the sake of pecuniary gain' (Morawetz, 1882: 3). In fact, 'there [was] no reason ... why a number of individuals should not be permitted to form a corporation of their own free will, and without first obtaining permission from the legislature, just as they may form a partnership or enter into ordinary contracts with each other (Morawetz, 1882: 24), save perhaps to prevent fraud. The new corporate law statutes helped mitigate the risk of fraud by imposing a requirement of due notice of incorporation for the benefit of third parties, most notably creditors, but beyond that, Morawetz seemed to imply, corporate law might be dispensed with.

Although corporate law formally created artificial persons with rights and duties of their own, it was imperative 'to bear in mind distinctly', warned Morawetz (1882: 2), 'that the existence of a corporation independently of its shareholders is a fiction; and that the rights and duties of an incorporated association', particularly as related to property, were 'in reality the rights and duties of the persons who compose it, and not of an imaginary being'. Since 'a corporation and its members [were] in reality one and the same' (Morawetz, 1882: 565-6), it was clear that 'ownership of everything belonging to an ordinary trading corporation [was] in the persons who compose it' (Morawetz, 1882: 385 ), and that 'debts due a corporation [were] in reality due to the body of stockholders' (Morawetz, 1882: 621).

Morawetz's partnership analogy, and the attendant invitation to dismiss the corporation's separate personality, were accepted by many legal scholars in 
search for a replacement for the defunct concession theory. ${ }^{8}$ 'The fiction of the "legal person"', wrote lawyer and historian Henry O. Taylor (1884: iv), was little more than an 'unnecessary mystification' that had 'outlived its usefulness' in the modern world. If substance was to be preferred over form, only the rights of the actual human beings involved mattered. After all, as Taylor (1884:14) put it, in terms of 'physical existences' there was only 'a collection of [natural] persons'. This 'aggregate theory' of the corporation, lauded by a later commentator as the first attempt to 'see the corporation as it really is' (Seymour, 1903: 549), soon found an echo in the courts. It informed key Supreme Court rulings in the 1880s, most notably Santa Clara. ${ }^{10}$

Paradoxically, although Santa Clara and the legislative ethos of the 1880s seemed to have legitimized the corporation as a private institution by using the partnership analogy, thereby favoring the emergence of big business, it was precisely the emergence of big business that led to the demise of aggregate theory by the end of the 1890s. The wave of horizontal integration in American industry that began in the mid-1890s after the passage of general incorporation laws for holding companies in New Jersey led to unprecedented corporate growth and market concentration, underpinned by the rapid development of a market for industrial securities. Over half of the consolidations undertaken during this 'great merger movement' absorbed more than $40 \%$ of their industries, and about a third absorbed more than 70\% (Chandler, 1990; Lamoreaux, 1985).

In light of these developments, as legal historians from Morton Horwitz (1985) to Richard Adelstein (2012) have explained, it became difficult to argue that the increasingly concentrated manufacturing conglomerates that were engaged in large-scale activities spanning multiple states, and had large and growing numbers of shareholders, were essentially like partnerships. Indeed, it became hard to deny the reality of corporate organization, as something distinct from an aggregate of shareholders, when vast economic power increasingly lay in the hands of professional managers and 'absentee ownership', to use Thorstein Veblen's (1923) famous expression, was more often than not the norm. In the 1890 s, however, an alternative theory of the corporation was unavailable in America.

The need for a new theory was reinforced by the fact that the uses and abuses of the corporate form were at the forefront of the public debate. A new generation

8 This development was aided by the popularity of Morawetz's treatise which, by the time of its second edition in 1886, had become a standard text in law schools. With its meticulous references to several thousand court cases it was considered as 'the best treatise on the subject of corporations' available by James Barr Ames, the influential Dean of Harvard Law School (cited in McClure, 2015: 3).

9 Prominent proponents of this view included Seymour D. Thompson (1895) and William L. Clark (1897). For a particularly clear statement see Benjamin Trapnell (1897).

10 Santa Clara County v. Southern Pacific R. Co., 118 US 394 (1886) extended the Fourteenth Amendment's equal protection clause and, by implication, due process, to corporate property, making it more difficult to tax differently from personal property. 
of muckraker journalists revealed practices of price fixing, rate discrimination, ruthless predatory tactics and outright fraud, contributing to the widespread perception that corporations were the 'tool of plutocracy' and a 'danger to the republic', as corporate lawyer and entrepreneur William W. Cook (1891: 251) put it. The sentiment that corporations had grown too large to be effectively constrained by state legislation, combined with the reluctance of courts to issue proceedings across state boundaries, put pressure on Congress, which responded by introducing the first federal regulations of corporate activity. ${ }^{11}$

Like many of their contemporaries, the founders of the American Economic Association observed these developments with apprehension. The problem with the new breed of corporations was not simply that they rendered obsolete the old rules of business conduct, wrote Henry Carter Adams (1891: 75), but that they laid claim to 'privileges ... originally intended for individuals alone'. Indeed, they 'interfered with the effective workings of the accepted system of jurisprudence, pertaining to the significance of rights and to the relation between rights and responsibilities' (Adams, 1897: 16-20). With limited liability, Richard T. Ely (1887: 976) concurred, 'the moral element [wa]s at its minimum': everyone involved in a corporation felt that they '[could not] be held personally responsible for its immoral conduct'. ${ }^{12}$

The fact that in large corporations the 'ownership of capital [wa]s separated from its management' (Ely, 1887: 973) meant that what the Cambridge economist D. H. Robertson (1923) later called capitalism's 'golden rule', namely the virtuous association of control with risk, was violated. The transformations of the American economy were so profound that traditional conceptions, including the belief that the power of making business decisions was most wisely exercised by those who stood to lose the most, a principle that made sense in a world of local competition between small businesses owners, needed to be reconsidered. But the fact that 'the nature of corporations ha[d] not yet been fully explained', observed Ely (1887: 975-7), was an impediment to any serious attempt to find 'some contrivance which will render artificial persons amenable to the moral law' of liability.

Similar conceptual concerns ran through the Congressional debates surrounding the problem of corporate taxation (Bank, 2010; Joseph, 2004). As the wealth held by the rising class of industrialists and bankers was increasingly taking the form of stock ownership, legislatures responding to public perceptions that the holders of this new wealth were not bearing their 'fair share' of the tax burden (Bank, 2010: 40), or were simply seeking to expand their tax base, were confronted with the question of how to reach this wealth. Since existing tax

11 A federal Interstate Commerce Commission was set up in 1887 to deal with pricing abuses by railroad corporations, and steps were taken to restrict combinations including the Sherman Antitrust Act in 1890 (Berk, 1997; Sklar, 1988).

12 Similar concerns were voiced by American classical economists (Giocoli, 2017). 
laws made no mention of corporations, having been devised when corporations were small and scarce, the only way forward was to assume that the property of artificial and natural persons was equally liable.

Taxing corporate property, however, was seen as taxing shareholders, given both the prevailing aggregate theory of the corporation and, as one would expect, protests from industrialists, bankers and other investors that they would be subjected to unfair double taxation. But while double taxation was 'not necessarily unjust', wrote Edwin R. A. Seligman (1890: 636), the Columbia economist who would soon become the nation's leading authority on public finance, clearly the idea of corporate taxation required some justification. Indeed, as Cook (1891: 102) put it, 'how to tax corporations, and how to tax them fully, yet fairly', was 'one of the most perplexing problems' of the day. Proposals to tax corporations at the federal level only compounded the problem.

A first attempt in this direction was made in the Revenue Act of 1894. The Act was struck down by the Supreme Court in 1895 even though, as the distinguished editor of the American Law Register, the country's oldest law journal, George Wharton Pepper (1895: 296) wryly observed, 'the nature of the corporation [was] still under discussion', and indeed despite strong differences of opinion regarding this key question among the Justices themselves. ${ }^{13}$ Arguably, the lack of consensus concerning what constituted a 'taxable entity' (Joseph, 2004: 86), and uncertainty regarding the equally important question of where to draw its boundaries, was in no small measure the result of the prevailing conceptual confusion about the nature of the corporation.

While the partnership analogy was a way to explain what Michigan lawyer and economist John Patterson Davis (1897: 280) called the 'voluntary inception' of corporations, a salient fact in the era of general incorporation, the claim that artificial personality was a metaphysical relic of the past that had outlived its usefulness seemed disputable. The 'existence of a corporation as a legal entity', wrote Baltimore lawyer Henry Winslow Williams (1899: 5), was not imaginary but a 'legal fact of the greatest practical importance' (Williams, 1899: 10). In the words of Dwight Arven Jones (1892: 80), a prominent member of the New York Bar, since the treatment of 'a corporation [as] a legal person' was 'necessary both to secure public rights against the corporation and to secure corporate rights against the public', the matter clearly warranted further investigation.

It is in this context that Freund's Legal Nature of Corporations was written and published. It is unclear whether it was Freund's intention to address the gaps in the American understanding of corporations, to show that corporations were not a danger to society, or to tackle, indirectly at least, the legislative problems of the day. Although in the preface he claimed that the investigation that followed was 'without immediate ... reference to practical questions' (Freund, 1897:

13 The Court later upheld the Corporate Tax Act of 1909. The principle of corporate taxation was firmly established in the Revenue Act of 1913. 
5), he acknowledged that his objective of establishing analytically the idea of 'the corporation [a]s a distinct person in law' (Freund, 1897: 10) might be of some practical value. In any case, Freund proposed a novel theory of the corporation that is well worth examining in some detail. As the rest of this paper demonstrates, his approach stood out in more ways than one.

\section{Freund's rational study of corporate law}

A distinguishing mark of Freund's book was its decidedly analytical approach. It was insufficient, Freund believed, to enumerate differences between incorporated and unincorporated associations, and unsatisfactory to rely on court cases and authorities from the past. And it was certainly unacceptable to make claims about such important matters as the nature of the corporation without at least some justification. The popular position exemplified by Morawetz and others at the time, who 'repudiate[d] the notion of the fictitious and artificial person' but 'deem[ed] it perfectly sufficient to proclaim the conception as false and contrary to reality' without 'even attempt[ing] an explanation' (Freund, 1897: 12) of why the notion even existed in law, simply begged the question. ${ }^{14}$

For Freund, the issue of whether the corporation was a public concession or a private association was misleading because neither perspective clearly explained the role played by its distinct personality. Freund proposed to address this question from the point of view of property law. If, as Morawetz had argued, corporations were essentially like partnerships, and all corporate property was in reality the shareholders' property, why would individuals forming a business association choose the corporate form over the partnership or other forms of joint ownership? What indispensable functions were performed by corporate law, besides the prevention of fraud? No previous attempt to examine the value of the corporate form from this perspective had been proposed. It is in this sense that Freund's book was the earliest example of the rational study of corporate law.

Freund's property perspective, and his approach, which contains the basic ingredients of what today would be recognized as comparative institutional analysis, led him to formulate answers that anticipated the thrust of recent work on firms and legal entities (Blair and Stout, 1999; Hansmann et al., 2006). In modern terms, Freund reasoned that members of business associations faced collective action and commitment problems, and that these were more or less mitigated by their choice of legal form, which varied in its capacity to secure property against both insider defection and against outsiders. This led him to demonstrate that the chief characteristics of the corporate form, namely a distinct personality and an independent board, offered the strong protections that neither contractual arrangements nor partnership law could achieve.

14 Freund's attitude was far from commonplace among American legal scholars in the 1890s. 
A stepping stone in Freund's thinking involved a reassessment of some of the fundamental conceptions underlying corporate theory. Like anyone studying law in Germany during the 1880s Freund was familiar with the corporate personality controversy (Gindis, 2009; Iwai, 1999), and had been exposed to the teachings of Otto von Gierke, a towering figure of the historical school whose Das Deutsche Genossenschaftsrecht led the attack on the concession theory associated with the school's founder, Friedrich Carl von Savigny. For Gierke, corporations were private associations but they were more than aggregates of their members. An organized and cohesive group such as a corporation was like 'a living organism and a real person, with body and members, and a will of its own' (Maitland, 1900: xxvi). Its personality stemmed from its group will, which pre-existed its incorporation; incorporation merely acknowledged an already existing fact.

Freund was the first to discuss Gierke's 'real person' theory of the corporation in America. ${ }^{15}$ While Horwitz (1985: 218) may be right that he sought to translate Gierke's ideas 'for a practical-minded and anti-metaphysical American Bar', Freund understood that Gierke's organicism and Morawetz's aggregate view suffered from the same defects. The failure of these 'prevailing theories of corporate existence', Freund explained, was due to their reliance on the 'orthodox view' of the nature of rights, namely that 'undivided personal volition [wa]s essential to the holding of a right' (Freund, 1897: 49). It was the implicit acceptance of this will theory of rights that led Morawetz to reduce corporate rights and duties to individual rights and duties, and its explicit acceptance that led Gierke to see 'every corporate act [a]s the manifestation of corporate will and therefore of corporate personality' (Freund, 1897: 76).

For Freund, a more adequate theory of corporations was one that rejected Gierke's 'strained view of the corporation as a real person' (Freund, 1897: 76). Corporations were not, as he sarcastically put it, 'a new and distinct species of humanity' (Freund, 1897: 52). At the same time, the requisite theory needed to account for the undeniable fact eschewed by Morawetz that for most, if not all, practical purposes law treated 'corporation and member as two absolutely different holders' of rights and duties (Freund, 1897: 41). The challenge was to show that corporate rights and duties were not 'abnormal and illogical' (Freund, 1897: 48), and that 'the treatment of the corporation as a legal person' (Freund, 1897: 83) was justified 'in connection with property and not with governmental rights' or privileges (Freund, 1897: 9).

In order to make sense of the corporation's status as a legal person, which Freund viewed as an 'instrument of legal reasoning' (Freund, 1897: 83) used to

15 Freund's book was published before Frederick W. Maitland's famous translation of sections of Volume 3 of the monumental Genossenschaftsrecht (Gierke, 1900), but it was the latter, given its author's stature as the pre-eminent English legal historian of his day, that was instrumental in disseminating Gierke's ideas in the Anglo-American world (Harris, 2006). 
determine the incidence of legal acts, ${ }^{16}$ Freund believed that another orthodox principle, namely that control over and interest in property must coincide in the same natural person, a principle that sat well with the will theory of rights, needed to be rejected. When rights were more usefully construed, following Rudolf von Jhering, as 'legally protected interests', the economic benefits of which were secured by some 'active . . element of control' (Freund, 1897: 15), ${ }^{17}$ it became easy to see that the 'two elements of a right, control and interest' (Freund, 1897: 17), particularly as related to property, were frequently separated. This possibility was particularly relevant to the corporate theorist. ${ }^{18}$

Of course, corporations could not be explained by the mere fact of 'separation of control and interest' (Freund, 1897: 16). ${ }^{19}$ Property held in trust, for instance, involved a separation but lacked the voluntary act of association that was essential to corporations. Likewise, corporations could not be understood by the mere fact of voluntary association. Private associations formed for the pursuit of common interests, such as literary societies, could achieve 'natural cohesion and organization' (Freund, 1897: 22), but were 'legally irrelevant'. Associations of this kind could not enter into contracts or become parties to litigation in their own right, any more than they could hold property in their own name. These features involved the exercise of 'legal control with reference to [the] common interests' (Freund, 1897: 21), and had to be constructed artificially, as it were, by either courts or statute law. ${ }^{20}$

To understand the role of law, and how an analytically meaningful distinction between partnerships and corporations could be derived, it was important to recognize why business associations were formed in the first place, and to consider the problems that associates were likely to face. As Freund (1897: 19) explained, in any association based on a 'combination of resources', the purpose of which was to 'bring returns to each party far in excess of what he would procure by the separate and independent employment of his own means', a key

16 Legal persons, wrote Freund (1897: 81), were simply 'distinctive parties of legal relations'. An advantage of this view of legal personhood, which is independent of the flesh-and-blood human being and the issue of volition, is that it avoids anthropomorphism and equivocation (Gindis, 2016).

17 From his exposure to German jurisprudence Freund (1890) retained above all the teachings of Jhering, whose influence on his view that 'the rule of law arises out of the conflict of human interests, which it tempers and regulates in accordance with the necessities of social existence' (Freund, 1897: 15), is clear. Jhering's (1879) jurisprudence was already translated and well known in America. Holmes (1881: 208) in particular referred to Jhering as 'a man of genius'.

18 Freund (1897: 48) explained: 'In dealing with associations of persons we must modify the ideas ... derived from the right of property in individuals [i.e. coincidence of control and interest], and what has first seemed to be an anomaly will appear simply as [a] legitimate form of development'.

19 This expression is equivalent to the common phrase, 'separation of ownership and control'. Freund had in mind control over and interest in (or ownership of) property.

20 While he accepted Gierke's idea that organized and cohesive associations were more than aggregates of their members, Freund (1897: 6) set aside 'the subject of association as a factor in economic, social and political life' to focus on the 'corporation as a legal institution' only. 
issue was whether the associates needed to exercise joint control to pursue their common interests. Given that disagreements over the proper course of action could arise, and in fact often did, particularly when the number of joint parties was large, the obstacle of what Freund (1897: 23) called 'concurrent action' needed to be overcome.

A common solution to this problem was the adoption of a decisionmaking procedure such as a majority rule that implied, according to Freund, a form of separation of control and interest. When associates agreed to this 'method of representative action' (Freund, 1897: 23) that he called 'original representation' (Freund, 1897: 24), ${ }^{21}$ each associate accepted the possibility that the representatives of the majority in control of the common interests might initiate actions that they may not individually desire. The associates' commitment to the association, despite this possibility, was therefore of central importance, as without it the association's survival over time was uncertain. Indicative of the level of commitment was the associates' choice of legal form through which to collectively pursue their interests.

Without legal form, Freund explained, control over the association's affairs could not be secured because the representatives of the majority would be unable to hold 'binding power' over members (Freund, 1897: 21). An association of this kind would be constantly subject to the possibility of breakup and dissolution. On the other hand, depending on the chosen legal form, control over the association's affairs could be more or less secured, and binding power over the members more or less established. Freund's argument was that incident to the adoption of a particular legal form was a certain degree of separation between control and interest, and that the greater the degree of separation the more 'the idea of the unity of the association as a holder of rights [was] justified' (Freund, 1897: 77).

American courts, Freund (1897: 26) observed, effectively recognized 'features of unity' in partnerships, routinely upholding the business convention that 'each partner is the representative of the firm' based on the reasoning that a partnership may outwardly 'appear as a unit' (Freund, 1897: 30), that this 'outward unity [wa]s expressed by a collective name and title' (Freund, 1897: 40), and that in ordinary business dealings this implied that partnerships contracted their own debts secured by the property held in common. ${ }^{22}$ The distinctiveness of the partnership, he wrote, also 'assert[ed] itself in equity in the matter of accounting and especially in the adjustment of individual and partnership liabilities with

21 To be distinguished from 'representative action under express delegation, by which joint rights are commonly exercised' based on the rules of agency, the main problem with 'the relation between agent and principal' being that it '[did] not solve entirely the difficulties of concurrent action' (Freund, 1897: 23-4).

22 As Morawetz and others, including Pepper (1898), had noted. 
their respective preferences as to individual and partnership property' (Freund, 1897: 26-7). ${ }^{23}$

An unincorporated partnership, however, could not be said to constitute a bona fide form of collective holding of property because the separation of control and interest remained rather weak. While 'the undivided control of partnership affairs' could be somewhat 'strengthened by contractual stipulations' (Freund, 1897: 27), partnerships lacked both an absolute protection against 'express dissent' and 'an unqualified recognition of majority rule' (Freund, 1897: 28). This meant that their duration could not be legally guaranteed. Since absolute security in business dealings with third parties could not be ensured, transactions beyond the ordinary course of business, where acquired reputations were insufficient, often proved to be risky for outsiders, and this condemned partnerships to relatively small sizes. ${ }^{24}$

By contrast, incorporation implied a complete separation of control and interest, because undivided control over corporate property lay entirely in the hands of a 'governing body', a board of directors (Freund, 1897: 58), whose position was 'different from that of mere agents' because its binding powers could not be revoked at any time, even 'by majority [shareholder] resolutions' (Freund, 1897: 59). Although specific members of the governing body could be under some conditions replaced, undivided control over corporate affairs by a governing body was an incident of the corporate form itself, and this 'regardless of the change of persons to whom the interest [was] secured' (Freund, 1897: $35)$. In this manner the 'continuity of the tie binding remaining and incoming members together' (Freund, 1897: 46) was ensured.

Properly understood, Freund elaborated, a corporation was a genuine 'property-holding body' (Freund, 1897: 42) whose members were 'not the part owners of the corporate property, nor part creditors or debtors of the corporate claims and obligations' (Freund, 1897: 9-10). Corporate property was completely separate from the personal property of its members, with the implication that 'a member [could] not set off a corporate claim against his own debt, nor a corporate debtor use a claim against a member for the like purpose' (Freund, 1897: 10). The fact that these features did not need to be established in courts but were a matter of statute law provided, from Freund's point of view, the ultimate 'security both against outsiders and against defection on the part of the members' (Freund, 1897: 22). This was therefore the primary reason for choosing the corporate form over the partnership or other forms of collective holding of property.

23 Civil law jurisdictions, Freund (1897: 27) observed, had gone further by formally recognizing the separate patrimony of partnerships, with the implication that actions could be brought by and against partnerships 'irrespective of changes in membership occurring'.

24 Freund (1897: 28) acknowledged that for business ventures based primarily or exclusively on personal trust and confidence these defects could in fact be construed as advantages, and indeed 'an expression of deliberate legal policy'. 
Arguably, given its 'unity, distinctiveness, and identity in succession' (Freund, 1897: 83), the treatment of the corporation as merely as a 'number of individuals' (Freund, 1897: 81) was mistaken. Because Morawetz thought that a theory of corporate existence involved dealing with 'undemonstrable entities' (Freund, 1897: 52), he failed to see that it was no more imaginary to treat the corporation as one, disregarding the separate existence of its members, than it was to treat a ship as one, disregarding its many separate parts. As long as the corporation was operative, in order to protect the conditions of undivided control, its members did not form the objects of separate legal dispositions but shared instead the 'legal status of the composite thing' (Freund 1897: 77). ${ }^{25}$

Thinking of this composite thing as a 'human agency devoted to distinct purposes' (Freund, 1897: 81), without qualifications, was Gierke's error. There was no need for metaphysical speculations about the existence and operation of the corporate will. Instead, in accordance with legal practice, the idea of 'corporate acting capacity' (Freund, 1897: 55) could be directly derived from 'act[s] done by corporate authorities in the corporate name' (Freund, 1897: 62). Corporations, after all, became 'visible and active in and through individuals only' (Freund, 1897: 77). As Freund (1897: 52) explained, 'when we speak of an act or an attribute as corporate, it is not corporate in the psychologically collective sense, but merely representative'.

As an instrument of legal reasoning, the 'idea of vicarious performance', Freund (1897: 56) observed, helped 'determine the incidence of the effects of legal acts done in the corporate name' (Freund, 1897: 82). By the same token, a 'representative wrong', such as liability for tort committed by an officer or an employee, could be established, with responsibility imputed to the 'corporation ... identified with its governing body' (Freund, 1897: 68). Likewise, 'in the case of non-compliance with a statutory regulation or the maintenance of a nuisance, there [wa]s ... no reason why an indictment [could] not lie against the corporation' itself (Freund, 1897: 69). ${ }^{26}$ For Freund, the attribution of acts, both positive and negative, to the corporation, 'even outside the jurisdiction of its creation' (Freund, 1897: 74), was sound legal policy.

The prevailing aggregate view could not conceptually accommodate a policy of this kind. In this respect, the superiority of Freund's theory of the corporation was evident. The corporate form, as Freund had shown, had grown out of the practical requirement to hold property in a manner that reduced the risks of internal defection and secured transactions with third parties. Clearly, unless it was fraudulently 'organized to hinder and delay creditors' (Freund, 1897: 79), in

25 Freund (1897: 78) pointed out that there was a difference between fictions based on the 'neglect of the irrelevant', such as the one operating in his analogy of composite things, and fictions involving 'the substitution of an imaginary conception for a substantial nonentity', which Morawetz thought were present in discussions of corporate personality.

26 Although in some cases a 'collective and mutual moral responsibility' (Freund, 1897: 69) would need to be established before criminal penalties could be sought against a corporation. 
which case its acts, and indeed its very incorporation, would be void, 'the security of transactions would be seriously impaired' (Freund, 1897: 55) if acts done in the corporate name were not systematically attributed to the corporation, that is, if the corporate person were disregarded at will.

\section{Freund's relevance, then and now}

Freund did not purport to address all of the pressing problems of the day, omitting for instance the topic of corporate taxation and barely mentioning the matter of limited shareholder liability. But when set against the concerns of his contemporaries Legal Nature of Corporations was a felicitous book. Arguably, it provided perhaps the first explanation of and justification for the separation of ownership and control. As Gregory Mark (1987: 1477) explained, the 'justification for management's assumption of control of corporate affairs' stemmed from the fact that management's 'undivided control was the necessary outcome of the nature of corporate property holding' (Mark, 1987: 1474). ${ }^{27}$ In effect, Freund showed that the separation of ownership and control was a desirable consequence of incorporation.

If Freund seemed less concerned than others about the negative consequences of corporate activity it was because his book did more than explain why the treatment of a corporation as a legal person was necessary to secure corporate property. It also explained that the treatment of a corporation as a legal person could help secure public rights against corporations. Liability for torts, nuisances and non-compliance with regulation could be assigned to corporations precisely because their distinct legal personality, in effect a point of imputation for both rights and duties, implied that they appeared in court as singular parties. In this respect, Freund's book justified 'the jurisdiction of state courts over corporate defendants' (Carrington, 1994: 488), presaging later developments.

Yet despite the manifest relevance of Freund's discussion for his contemporaries' preoccupations, and notwithstanding an early endorsement by no less a figure than Pepper (1897), whose review of Clark's (1897) handbook based on the aggregate theory invited readers to study the more satisfying work by Freund, his book received little immediate attention. Some attention came after Maitland's translation of Gierke (1900). For instance, it was briefly mentioned alongside Gierke by Charles B. Elliott (1900). But again, despite Pepper's (1901) suggestion that Freund's analysis was superior to Gierke's, the book was rarely cited. ${ }^{28}$ It was overlooked in Davis' (1905) otherwise penetrating

27 Accordingly, not only did Freund's book 'anticipat[e] the classic Berle and Means discussion of the separation of ownership and control by several decades' (Mark, 2006: 1485), but 'Freund's brilliant exposition ... remains the intellectual foundation of the position of management' (Mark, 1987: 1474).

28 In England, where Maitland cast a long shadow on the development of corporate theory, with the exception of Cecil Thomas Carr's (1905: 200) approving mention of 'a most instructive essay by Dr Freund', it seems that Freund's book was barely noticed. 
study. Freund himself had by this time lost interest in corporate theory, turning his attention to administrative law and legislation. ${ }^{29}$

Nearly a decade passed before the first, and at the time only, discussion of Freund's book was published. Its author, Philadelphia lawyer George F. Deiser, devoted several pages to Freund's book in a series of articles explicitly attempting to outline a corporate theory without 'spectral attributes' that could provide 'a working basis for the solution of corporate problems' (Deiser, 1909: 314). ${ }^{30}$ From a similar perspective, but without citing Freund, Harvard's widely respected John Chipman Gray (1909: 54) argued that Jhering's conception of rights as legally protected interests could be mobilized to explain the issue of corporate liability without the 'dogmatic speculations' associated with Gierke: legal duties could be imposed on corporations 'to protect the rights of other persons, including the rights of individual members of the corporation'. Freund would have agreed.

The search for legal solutions to economic and social problems runs through his concern with what he called the 'problem of intelligent legislation' (Freund, 1907). As the noted legal philosopher Morris R. Cohen (1937: 316-17) observed, 'Freund ... always sought to find a genuinely rational pattern' that might 'help to clear the ground of much legal superstition' and 'supply illuminating ideas on the direction in which the law can wisely be pushed'. Freund (1900: 27) believed that the 'striking ... lack of uniformity' between state laws on all manner of issues meant that the appropriate direction, at least as an 'ideal in legislation' (Freund, 1917: 248), involved standardization. But he knew that attempts to achieve uniformity of local legislation were often unsuccessful, particularly 'as regards corporate organization, powers, relations, and liabilities' (Freund, 1917: 169).

These considerations played an important role in the debates surrounding the legal status of unincorporated associations such as partnerships. ${ }^{31}$ The judicial recognition of the mercantile view of partnerships as de facto legal persons was widespread, as Freund and many others had acknowledged. ${ }^{32}$ But the recognition of the partnership's rights and liabilities as distinct from those of the partners, and the subordination of the latter to the former, was far from uniform. This created some uncertainty, particularly in matters of interstate commerce. Like Columbia's Francis M. Burdick (1909) and others, Freund (1912: 107) claimed

29 There are sections and chapters on corporations in his major works but nothing resembling corporate theory. Legal Nature of Corporations was never cited in subsequent work.

30 Writing around the time when the Supreme Court's ruling in New York Central Hudson River Railroad $v$. United States, 212 US 481 (1909) sanctioned the idea that corporations could be subjected to criminal prosecution, Deiser was particularly interested in theoretical justifications for attributing liability to large corporations (Hager, 1989).

31 The legal status of trade unions was also under discussion.

32 A long list of such cases was compiled by William Hamilton Cowles (1903). 
that the situation called for a uniform partnership law that 'recognize[d] the firm as formal holder of rights', especially as regards to property. ${ }^{33}$

The drafters of the Uniform Partnership Act of 1914 attempted to agree, as its chief drafter William Draper Lewis (1911: 100) explained, on 'such fundamental matters as the legal nature of a partnership, the rights of the members in partnership property, or even their relation to third persons', but failed to do so in a logically coherent manner, as Scott Rowley (1916), Judson Adams Crane (1916) and other commentators pointed out. The Act did not formally define the partnership as a legal person, and its language was ambiguous: it recognized that partnerships as such could hold property but at the same time that partners were co-owners of this property. ${ }^{34}$ In the words of Michigan's Joseph H. Drake (1917: 626), the statute recognized 'the composite entity of the group and not the unit entity of an extrinsic juristic person'.

It would take 80 years for this anomaly to be settled in a manner that Freund would have approved of: the formal definition of the partnership as 'an entity distinct from its partners' was enshrined in the Revised Uniform Partnership Act of 1994 (\$201a). Among other things the new statute provided that the partnership property was owned by the legal entity rather than by the partners, meaning that partners were no longer co-owners of this property; that this property was protected from both the partners and their creditors; and that the partnership was not dissolved in the event of partner dissociation (Ribstein, 2010; Vermeulen, 2003). Freund would have appreciated the considerable enhancement of the separation of control and interest, but would have noted that the separation remained relatively weak.

He would have underlined the fact that the presence of a governing body with undivided control over partnership property was not an incident of this new partnership form. ${ }^{35}$ Although he would have acknowledged that partners might form a board by contractual stipulation he would certainly have pointed out that it would be impossible to guarantee either an absolute protection against express dissent or an unqualified recognition of majority rule. Indeed, Freund would have argued, the Act $(\$ 401 \mathrm{j})$ provided that partnership affairs were to be governed by majority rule only in the ordinary course of business, beyond which this method of representative action was replaced by unanimity. Hence the

33 As Freund (1904: 356) had explained, the status of partnerships and unincorporated associations was 'uncertain and unsatisfactory' because 'the right to hold property in corporate capacity' could not be completely guaranteed by contractual stipulations between the members.

34 The Act also did not achieve consistency with existing legislation such as the Bankruptcy Act of 1898, which clearly construed partnerships as falling under the category of 'persons' alongside corporations.

35 This does not mean that partnerships typically lack a governing body but simply that its presence is not required by law (Kraakman et al., 2009). The flexibility of partnership law implies that partners can unanimously resolve to form a board, just as they can subsequently choose to remove it. 
separation of control and interest could never be complete. For those in search of greater security Freund would have recommended the corporate form.

Despite differences in terminology Hansmann and his colleagues would no doubt accept this logic. Arguably, Freund's relatively simple framework shares much in common with the more sophisticated recent scholarship on firms and legal entities. In the main, Freund's contrast between weak and strong degrees of separation between control and interest is very similar to Hansmann et al.'s (2006) distinction between weak and strong degrees of entity shielding. In both cases the distinction revolves around the idea that what really matters for a meaningful comparison of alternative business associations is not limited liability but the degree to which an association's property is secured against both insiders and outsiders. ${ }^{36}$ In both cases the essential role played by law in this respect is emphasized.

To accomplish this task Freund rejected the claim popular among his contemporaries that the corporation's separate personality was a misleading fiction in the same way that Hansmann and his colleagues distanced themselves from a similar concern raised by prior contributors to the economic analysis of corporate law. And by distinguishing the 19th-century literature on corporate personality, which was 'principally concerned with ... the power of the state versus the power of private organizations, or the nature of group will', and their own approach, which adopted a 'simpler, clearer, and more functional' view that emphasized 'separate patrimony as a key characteristic of a juridical person', Hansmann and Kraakman (2000a: 439) unwittingly recognized Freund and his property perspective as an early example of their functional approach.

Of course, there are substantial differences between the two frameworks. Most notably, Freund had little to say about creditor rights and the liquidation protection that for Hansmann et al. is what defines the strong entity-shielding characteristic of the corporate form. And while Freund acknowledged that the subordination of personal to business claims in both partnerships and corporations was important his argument did not depend on this issue. Although he understood that transactions that were poorly or insufficiently secured were uncertain, his discussion was framed in neither the language of transaction costs nor the logic of efficiency. ${ }^{37} \mathrm{He}$ also focused more on the benefits of the corporate form than he did on the costs. But without having the shoulders of giants to stand on his analysis was, quite remarkably, on the right track.

A case can be made for the fact that, intuitively, Freund had the mind of an institutional economist, and formulated his argument in the spirit of what would become, following Coase, the theory of the firm. Granted, he did not identify the cost advantage that an association may have over ordinary market

36 Freund clearly viewed limited liability as secondary but did not provide a justification, unlike Hansmann et al.

37 Of course, few (if any) economists, let alone lawyers, reasoned in these terms at the time. 
exchange, but he did assume, in line with Armen Alchian and Harold Demsetz's (1972) thinking, that an association of resource owners would only exist if it was possible to generate a super-additive surplus. He then focused on how to best safeguard this mutually beneficial interest despite some of the collective action and commitment problems involved, and this led him to compare alternative institutional arrangements in light of the degree to which they helped prevent the potential failure of cooperation.

The consequences of internal defection were greatest in forms of association where control was jointly exercised and concurrent action was necessary, he reasoned, but even when joint control and concurrent action were no longer strictly necessary because a majority decision rule had been adopted, the problem of internal defection remained. To be truly protected from internal defection, associations had to exercise control over the combined resources in a manner that ensured the continuity of the tie binding remaining and incoming members together. To paraphrase Oliver Hart (1995), some sort of glue was needed to hold the association together over time. Freund realized that contractual arrangements alone would not suffice. He therefore turned his attention to the main legal forms of association available, and more specifically to the corporate form.

Incorporation vested ownership of the combined resources in the legal entity, and attributed unified control over corporate property to a board whose binding powers could survive changes in the association's membership. This was not just the best way to ensure the association's continuity but also the best way to secure transactions with outside parties. Blair and Stout (1999) would concur. There are clear parallels between Freund's reasoning and their team production theory of corporate law. Moreover, as Blair (2003) argued, the possibility of locking capital in was precisely what corporate law achieved for business organizers at the time when Freund was writing. Corporations were thus able to accumulate the specific investments that came to define advanced industrial economies.

\section{Conclusions}

Freund's Legal Nature of Corporations has rightly been identified as a brilliant exposition of the theoretical underpinnings of corporate law that was well ahead of its time (Carrington, 1994; Harris, 2006; Horwitz, 1985; Mark, 1987; Millon, 1990). But prior to the detailed discussion proposed in this paper, a systematic assessment of the book's contributions remained unavailable. As a result, Freund's recognition as an important but unjustly neglected corporate theorist has long been overdue. This paper has shown that Freund's property perspective on the corporate form helped establish analytically the role played by the corporation's distinct legal personality and offered, among other things, perhaps the first explanation of the separation of ownership and control, along with perhaps the first justification for the assignment of liability to corporations. 
These significant results were the product of Freund's distinctively analytical approach and his commitment to the rational study of law. Remarkably, Freund's study of the ends sought by corporate law and the reasons for desiring them was based on a seemingly intuitive understanding of what today would be called comparative institutional analysis, implicitly formulated in the spirit of the typical theory of the firm narrative. Freund assessed the main legal forms of association available at the time in terms of the degree to which they protected the members' combined property against the risks of internal defection while securing transactions with outside parties, and showed that contractual stipulations among partners could never provide the kind of security afforded by the corporate form as a matter of law.

Freund hence anticipated by roughly a century the main thrust of recent scholarship on the firm. As demonstrated in this paper, despite differences in terminology and emphasis, Freund's comparative assessment of partnerships and corporations in terms of the degree of separation of control and interest foreshadowed Hansmann, Kraakman and Squire's (2006) distinction between weak and strong entity shielding. And his claim that the advantage of the complete separation of control over and interest in property characteristic of the corporate form was to be found in the undivided control over corporate affairs by a governing body prefigured Blair's (2004) similar point. The resemblance between Freund's reasoning and the logic underlying Blair and Stout's (1999) team production theory of corporate law is equally striking.

The fact that Freund deserves to be recognized as a precursor of today's rational study of corporate law underscores just how much ahead of its time his book really was. But it also raises the question of why, given all that it had to offer, references to Freund's corporate theory are all but absent in the literature. Part of the responsibility lies with commentators who have mispresented Freund as the leading American exponent of Gierke's theory, claiming that 'moderate[s] ... tried to establish positions ... between the extremes presented by Freund and Morawetz' (Bratton, 1989: 1508). A more careful reading, however, shows that Freund discarded the dubious aspects of Gierke's theory, and is more accurately described as a moderate between the extreme positions defended by Gierke and Morawetz. This paper sets the record straight in that respect.

Regardless, the book's fate was probably sealed from the outset not simply by the scarce attention it received in the years following its publication but because Freund, reacting perhaps to the feeling that his ideas had a 'less receptive audience than they deserved' among lawyers 'unused to abstract and theoretical legal analysis' (Reitz, 1993: 431), never returned to corporate theory, or even cited his book in subsequent work. Since Freund did not remain an 'active player' in corporate law discourse, the prospects of his book being remembered, let alone canonized, were meager (Harris, 2006: 1435). One can only wonder what course the literature on corporations might have taken had Freund remained, while pursuing his other endeavours, an active participant in the debate. 


\section{References}

Adams, H. C. (1891), 'Statistics as a Means of Correcting Corporate Abuses', Publications of the American Economic Association, 6(1-2): 73-8.

Adams, H. C. (1897), Economics and Jurisprudence, New York: Macmillan.

Adelstein, R. P. (2012), The Rise of Planning in Industrial America, 1865-1914, London: Routledge.

Alchian, A. A. and H. Demsetz (1972), 'Production, Information Costs and Economic Organization', American Economic Review, 62(5): 777-95.

Allen, F. A. (1965), 'Ernst Freund and the New Age of Legislation', Law School Record, 13(1): $1-14$.

Angell, J. K. and S. Ames (1832), A Treatise on the Law of Corporations Aggregate, Boston, MA: Little \& Brown.

Ayotte, K. and H. Hansmann (2015), 'A Nexus of Contracts Theory of Legal Entities', International Review of Law and Economics, 42: 1-12.

Bank, S. A. (2010), From Sword to Shield: The Transformation of the Corporate Income Tax, 1861 to Present, New York: Oxford University Press.

Berk, G. (1997), Alternative Tracks: The Constitution of American Industrial Order: 1865-1917, Baltimore, MD: Johns Hopkins University Press.

Blair, M. M. (2003), 'Locking-In Capital: What Corporate Law Achieved for Business Organizers in the Nineteenth Century', UCLA Law Review, 51(2): 387-455.

Blair, M. M. (2004), 'The Neglected Benefits of the Corporate Form: Entity Status and the Separation of Asset Ownership from Control', in A. Grandori (ed.), Corporate Governance and Firm Organization: Microfoundations and Structural Forms, New York: Oxford University Press.

Blair, M. M. (2012), 'The Four Functions of Corporate Personhood', in A. Grandori (ed.), Handbook of Economic Organization, Cheltenham: Edward Elgar.

Blair, M. M. and L. A. Stout (1999), 'A Team Production Theory of Corporate Law', Virginia Law Review, 85(2): 247-328.

Bratton, W. W. (1989), 'The New Economic Theory of the Firm: Critical Perspectives from History', Stanford Law Review, 41(6): 1471-527.

Burdick, F. M. (1909), 'Partnership Realty', Columbia Law Review, 9(3): 197-216.

Carr, C. T. (1905), The General Principles of the Law of Corporations, Cambridge: Cambridge University Press.

Carrington, P. D. (1994), 'The Missionary Diocese of Chicago', Journal of Legal Education, 44(4): 467-518.

Chandler, A. D. (1990), Scale and Scope: The Dynamics of Industrial Capitalism, Cambridge, MA: Harvard University Press.

Clark, W. L. (1897), Handbook of the Law of Private Corporations, St. Paul, MN: West Publishing Co.

Coase, R. H. (1937), 'The Nature of the Firm', Economica, 4(16): 386-405.

Cohen, M. R. (1937), 'A Critical Sketch of Legal Philosophy in America', in A. Reppy (ed.), Law: A Century of Progress 1835-1935, New York: New York University Press.

Cook, W. W. (1891), The Corporation Problem, New York: Putnam's Sons.

Cowles, W. H. (1903), 'The Firm as a Legal Person', Central Law Journal, 57: 343-53.

Crane, J. A. (1916), 'The Uniform Partnership Act and Legal Persons', Harvard Law Review, 29(8): 838-50.

Davis, J. P. (1897), 'The Nature of Corporations', Political Science Quarterly, 12(2): 273-94. 
Davis, J. P. (1905), Corporations: A Study of the Origin and Development of Great Business Combinations and of their Relation to the Authority of the State, New York: G.P. Putnam's Sons.

Deakin, S. (forthcoming), 'Juridical Ontology and the Theory of the Firm', in F. Gagliardi and D. Gindis (eds), Institutions and Evolution of Capitalism: Essays in Honour of Geoffrey M. Hodgson, Cheltenham: Edward Elgar.

Deakin, S., D. Gindis, G. M. Hodgson, K. Huang and K. Pistor (2017), 'Legal Institutionalism: Capitalism and the Constitutive Role of Law', Journal of Comparative Economics, 45(1): 188-200.

Deiser, G. F. (1909), 'The Juristic Person', University of Pennsylvania Law Review and American Law Register, 57(5): 300-14.

Drake, J. H. (1917), 'Partnership Entity and Tenancy in Partnership: The Struggle for a Definition', Michigan Law Review, 15(8): 609-30.

Easterbrook, F. H. and D. R. Fischel (1991), The Economic Structure of Corporate Law, Cambridge, MA: Harvard University Press.

Elliott, C. B. (1900), A Treatise on the Law of Private Corporations, 3rd edition, Indianapolis, IN: Bowen-Merrill.

Ellsworth, F. L. (1977), Law on the Midway: The Founding of the University of Chicago Law School, Chicago: University of Chicago Press.

Ely, R. T. (1887), 'The Nature and Significance of Corporations', Harper's New Monthly Magazine, 74(444): 970-7.

Ernst, D. R. (2014). Tocqueville's Nightmare: The Administrative State Emerges in America, 1900-1940, New York: Oxford University Press.

Evans, G. H. (1948), Business Incorporations in the United States, 1800-1943, New York: NBER.

Firmage, E. B. (1962), 'Ernst Freund: Pioneer of Administrative Law', University of Chicago Law Review, 29(4): 755-81.

Freund, E. (1890), 'Historical Jurisprudence in Germany', Political Science Quarterly, 5(3): 468-86.

Freund, E. (1897), The Legal Nature of Corporations, Chicago: University of Chicago Press.

Freund, E. (1900), 'Government and Law in America', American Law Review, 34(1): 16-27.

Freund, E. (1904), The Police Power: Public Policy and Constitutional Rights, Chicago: Callaghan.

Freund, E. (1907), 'The Problem of Intelligent Legislation', Proceedings of the American Political Science Association, 4: 69-79.

Freund, E. (1912), 'Unifying Tendencies in American Legislation', Yale Law Journal, 22(2): 96-113.

Freund, E. (1917), Standards of American Legislation, Chicago: University of Chicago Press.

Freund, E. (1928), Administrative Powers over Persons and Property: A Comparative Study, Chicago: University of Chicago Press.

Gierke, O. (1900), Political Theories of the Middle Age, translated with an introduction by F. W. Maitland, Cambridge: Cambridge University Press.

Gindis, D. (2009), 'From Fictions and Aggregates to Real Entities in the Theory of the Firm', Journal of Institutional Economics, 5(1): 25-46.

Gindis, D. (2016), 'Legal Personhood and the Firm: Avoiding Anthropomorphism and Equivocation', Journal of Institutional Economics, 12(3): 499-513. 
Giocoli, N. (2017), “'Love Me, Love Me Not”: The Complicated Affair between Classical Economics and American Corporations during the Gilded Age', unpublished, available at https://ssrn.com/abstract=2952717 (accessed 31 October 2017).

Gray, J. C. (1909), The Nature and Sources of the Law, New York: Columbia University Press.

Hager, M. M. (1989), 'Bodies Politic: The Progressive History of Organizational "Real Entity" Theory', University of Pittsburgh Law Review, 50(3): 575-654.

Hansmann, H. and R. Kraakman (2000a), 'The Essential Role of Organizational Law', Yale Law Journal, 110(3): 387-440.

Hansmann, H. and R. Kraakman (2000b), 'Organizational Law as Asset Partitioning', European Economic Review, 44(4-6): 807-17.

Hansmann, H., R. Kraakman and R. Squire (2006), 'Law and the Rise of the Firm', Harvard Law Review, 119(5): 1333-403.

Harris, R. (2006), 'The Transplantation of the Legal Discourse on Corporate Personality Theories: From German Codification to British Political Pluralism and American Big Business', Washington and Lee Law Review, 63(4): 1421-78.

Hart, O. D. (1995), Firms, Contracts and Financial Structure, New York: Oxford University Press.

Hodgson, G. M. (2002), 'The Legal Nature of the Firm and the Myth of the Firm-Market Hybrid', International Journal of the Economics of Business, 9(1): 36-60.

Holmes, O. W. (1881), The Common Law, Boston: Little, Brown \& Co.

Holmes, O. W. (1897), 'The Path of Law', Harvard Law Review, 10(8): 457-78.

Horwitz, M. J. (1985), 'Santa Clara Revisited: The Development of Corporate Theory', West Virginia Law Review, 88(2): 174-224.

Horwitz, M. J. (1992), The Transformation of American Law, 1870-1960: The Crisis of Legal Orthodoxy, New York: Oxford University Press.

Hovenkamp, H. (1991), Enterprise and American Law, 1836-1937, Cambridge, MA: Harvard University Press.

Hurst, J. W. (1970), The Legitimacy of the Business Corporation in the Law of the United States, 1780-1970, Charlottesville, VA: University of Virginia Press.

Hurst, J. W. (1982), Law and Markets in United States History: Different Modes of Bargaining Among Interests, Madison, WI: University of Wisconsin Press.

Iacobucci, E. M. and G. G. Triantis (2007), 'Economic and Legal Boundaries of the Firm', Virginia Law Review, 93(3): 515-70.

Iwai, K. (1999), 'Persons, Things and Corporations: The Corporate Personality Controversy and Comparative Corporate Governance', American Journal of Corporation Law, 47(4): 583-632.

Jensen, M. C. and W. H. Meckling (1976), 'Theory of the Firm: Managerial Behavior, Agency Costs and Capital Structure', Journal of Financial Economics, 3(4): 305-60.

Jhering, R. (1879), The Struggle for Law, translated by John J. Lalor, Chicago: Callaghan \& Co.

Jones, D. A. (1892), 'A Corporation as “A Distinct Entity”, Councellor, 2(3): 78-81.

Joseph, R. J. (2004), The Origins of the American Income Tax: The Revenue Act of 1894 and Its Aftermath, Syracuse. NY: Syracuse University Press.

Kent, A. H. (1933), 'Ernst Freund (1864-1932): Jurist and Social Scientist', Journal of Political Economy, 41(2): 145-51.

Kent, J. (1827), Commentaries on American Law, New York: O. Halsted. 
Klein, W. A. (1982), 'The Modern Business Organization: Bargaining under Constraints', Yale Law Journal, 91(8): 1521-64.

Kornhauser, L. A. and B. MacLeod (2013), 'Contracts between Legal Persons', in R. Gibbons and J. Roberts (eds), Handbook of Organizational Economics, Princeton, NJ: Princeton University Press.

Kraakman, R., J. Armour, P. Davies, L. Enriques, H. Hansmann, G. Hertig, K. Hopt, H. Kanda and E. Rock (2009), The Anatomy of Corporate Law: A Comparative and Functional Approach, 2nd ed., New York: Oxford University Press.

Kraines, O. (1974), The World and Ideas of Ernst Freund: The Search for General Principles of Legislation and Administrative Law, Tuscaloose, AL: University of Alabama Press.

Lamoreaux, N. R. (1985), The Great Merger Movement in American Business, 1895-1904, Cambridge: Cambridge University Press.

Langlois, R. N. (forthcoming), 'The Corporation Is Not a Nexus of Contracts, It's an iPhone', in F. Gagliardi and D. Gindis (eds), Institutions and Evolution of Capitalism: Essays in Honour of Geoffrey M. Hodgson, Cheltenham: Edward Elgar.

Lewis, W. D. (1911), 'The Desirability of Expressing the Law of Partnership in Statutory Form', University of Pennsylvania Law Review and American Law Register, 60(2): 93-102.

Maine, H. S. (1861), Ancient Law: Its Connection with the Early History of Society and Its Relations to Modern Ideas, London: John Murray.

Maitland, F. W. (1900), 'Translator's Introduction', in O. Gierke, Political Theories of the Middle Age, translated with an introduction by F. W. Maitland, Cambridge: Cambridge University Press.

Mark, G. A. (1987), 'The Personification of the Business Corporation in American law', University of Chicago Law Review, 54(4): 1441-83.

Mark, G. A. (2006), 'Personification in Three Legal Cultures: The Case of the Conception of the Corporate Unit', Washington and Lee Law Review, 63(4): 1479-87.

McClure, M. (2015), 'Victor Morawetz, Draftsman of Political-Economy: A Study in Constitutional Constraints and Solutions in the Era of Reform', Business and Economic History On-Line, 13: 1-27.

Meckling, W. H. and M. C. Jensen (1983), 'Reflections on the Corporation as a Social Invention', Midland Corporate Finance Journal, 1(3): 6-15.

Millon, D. (1990), 'Theories of the Corporation', Duke Law Journal, 39(2): 201.

Morawetz, V. (1882), A Treatise on the Law of Private Corporations Other Than Charitable, Boston, MA: Little, Brown \& Co.

Mordfin, R. I. and M. F. Nagorsky (2011), 'Chicago and Law and Economics', Law School Record, 58(1): 8-17.

Orts, E. W. (2013), Business Persons: A Legal Theory of the Firm, New York: Oxford University Press.

Pepper, G. W. (1895), 'Recent Development of Corporation Law by the Supreme Court of the United States', American Law Register and Review, 43(5): 296-313.

Pepper, G. W. (1897), 'Review: William L. Clark, Handbook of the Law of Private Corporations', American Law Register and Review, 45(7): 477-9.

Pepper, G. W. (1898), 'Partnership Property', American Law Register, 46(5): 295-309.

Pepper, G. W. (1901), 'A Brief Introduction to the Study of the Law of Association', American Law Register, 40(5): 255-69.

Posner, R. A. (1990), The Problems of Jurisprudence, Cambridge, MA: Harvard University Press. 
Reitz, J. C. (1993), 'The Influence of Ernst Freund on American Law', in M. Lutter, E. C. Stiefel and M. H. Hoeflich (eds), Der Einfluß deutscher Emigranten auf die Rechtsentwicklung in den USA und Deutschland, Tübingen: J. C. B. Mohr (Paul Siebeck).

Ribstein, L. E. (2010), The Rise of the Uncorporation, New York: Oxford University Press.

Robertson, D. H. (1923), The Control of Industry, Cambridge: Cambridge University Press.

Rowley, S. (1916), The Modern Law of Partnership, Indianapolis, IN: Bobbs-Merrill Company.

Seligman, E. R. A. (1890), 'The Taxation of Corporations', Political Science Quarterly, 5(4): 636-76.

Seymour, E. B. (1903), 'Historical Development of the Common-Law Conception of a Corporation', American Law Register, 51(9): 529-51.

Sklar, M. J. (1988), The Corporate Reconstruction of American Capitalism, 1890-1916: The Market, the Law and Politics, Cambridge: Cambridge University Press.

Spulber, D. F. (2009), The Theory of the Firm: Microeconomics with Endogenous Entrepreneurs, Firms, Markets and Organizations, Cambridge: Cambridge University Press.

Taylor, H. O. (1884), A Treatise on the Law of Private Corporations having Capital Stock, Philadelphia, PA: Kay \& Brother.

Thompson, S. D. (1895), Commentaries on the Law of Private Corporations, San Francisco: Bancroft-Whitney.

Trapnell, B. (1897), 'The Logical Conception of the Corporation', American Lawyer, 5(1): 12-14.

Triantis, G. G. (2012), 'The Personification and Property of Legal Entities', in K. Ayotte and H. E. Smith (eds), Research Handbook on the Economics of Property Law, Cheltenham: Edward Elgar.

Tullock, G. (1971), The Logic of the Law, New York: Basic Books.

Van Den Steen, E. (2010), 'Interpersonal Authority in the Theory of the Firm', American Economic Review, 100(1): 466-90.

Veblen, T. (1923), Absentee Ownership and Business Enterprise in Recent Times: The Case of America, New York: Huebsch.

Vermeulen, E. P. M. (2003), The Evolution of Legal Business Forms in Europe and the United States: Venture Capital, Joint Venture and Partnership Structures, The Hague: Kluwer.

Williams, H. W. (1899), 'An Inquiry into the Nature and Law of Corporations', American Law Register, 47(1): 1-16. 